Full Length Research Paper

\title{
Effect of Hands-on Activity-Based Method on Interest of Senior Secondary Students in Organic Chemistry
}

\section{Oluwatosin Victor Ajayi}

\author{
Department of Curriculum and Teaching, Benue State University, PMB 102119, Makurdi, Nigeria \\ Email: drvictorajayi@gmail.com.
}

Accepted 4 May, 2017

\begin{abstract}
The study investigated the effect of hands-on activity-based method on interest of senior secondary chemistry students in organic chemistry. The study adopted a quasi-experimental design. A sample of 184 students from four purposively selected secondary schools out of a population of 2,381 SS II students from Makurdi Local Government Area of Benue State, Nigeria was used for the study. The experimental group was taught organic chemistry using hands-on activity-based method while the control group was taught using discussion method. Two research questions and two hypotheses guided the study. A validated 25-item Organic Chemistry Interest Inventory (OCII) was the instrument used to collect data. Reliability coefficients of 0.84 were established using Cronbach Alpha. Mean and Standard Deviation scores were used to answer the research questions while Analysis of Covariance (ANCOVA) was used to test the hypotheses at 0.05 level of significance. The results indicated that students taught using hands-on activity-based had significantly higher mean interest scores than those taught using discussion method $(F=387.370, P(0.0001<0.05)$. Male and female students in hands-on activity-based group did not differ significantly in mean interest scores $(F=117.523, P(0.101>0.05)$. It was recommended that teachers should be encouraged to adopt hands-on activity-based method in teaching organic chemistry to enhance students' interest in organic chemistry.
\end{abstract}

Key words: Hands-on activity-based, interest, organic chemistry.

\section{INTRODUCTION}

Chemistry plays a vital role in scientific and technological advancement of any nation and is one of the core science subjects taught in schools. Chemistry is an experimental science that systematically studies the composition, properties and activities of organic and inorganic substances and various elementary forms of matter (Senese, 2010). Its study involves exploration of relationship between theory and experiment. Organic Chemistry which is the main focus of this study is the Chemistry of carbon compounds and has been found very useful in different fields of science and technology. It is utilized in petrochemical industries, wine and alcohol processing production. Chemistry is a very important subject as its knowledge is required for the successful study in many important professions. Because of its importance, chemistry is occupying a pride of place in the senior secondary school curriculum.
However, the West African Examination Council (WAEC) Chief Examiners report (2015/2016) on Chemistry result indicates that students are weak in observation, identification of problems, lack recording and mathematical skills with poor practical/experimental exposure, also, due to abstractness in some organic Chemistry concepts in the Senior Secondary School Certificate (SSCE) Chemistry syllabus such as alkane, alkene, alkynes, carboxylic acid and fat and oil. This situation of fluctuation in achievement of students has affected the interest and education pursuits of many candidates who aspired to study professional courses in higher institutions. In this regards, Olorunyomi (2013) also noted that discussion method is popular in teaching/learning of SSCE organic Chemistry concept in Nigeria despite its limitations.

According to Olorunyomi (2013) discussion method is 
teacher-centered as it does not involve the learners enough participation. The author concludes that discussion method may degenerate into mere talk and may be monopolized by few individuals. Bamidele (2009) concluded in his study that students' interest in Chemistry is jeopardized by the teachers' authoritarian and introverted styles. These styles reduce Chemistry to a series of formulas and equations written on the chalkboard which make little or no meaning to the students. The author advocated the use of self-learning devices as a way of getting students interested in Chemistry. There is need to teach Chemistry in an inspiring manner in order to achieve meaningful learning. Interest is an important variable in learning because when one becomes interested in an activity one is likely to be deeply involved and inspired to learn.

However, interest in organic chemistry can only be result oriented when students are willing and the teachers are favorably disposed to use appropriate methods that could promote learners interest and active participation in the teaching/learning processes such as hands-on activity-based. Tile (2013) described hands-on activitybased as a situations where a learner uses his/her hands in carrying out activities that could enhance his/her experiences, therefore enhancing his/her interest in such concepts. Abudullai (2013) viewed hands-on activitybased as a method of teaching whereby students are engaged actively in class activities with the use of their hands and intellect under the guidance of the teacher.

In the same vein, Ayuba (2013) noted that chemistry is not inherently a boring subject. The teaching of Chemistry determines to a great extent whether a student have or loses interest in the subject. A good teacher could create interest even in the dullest students. The author concludes that a more creative and student-centered method such as hands-on activity-based to chemistry lessons with a good presentation of instructional materials might get more learners interested in the subject. Some studies indicate that boys had higher interest in chemistry (Kingdon, 2009), either no difference (Ajayi, 2016) or girls outperform boys (Calsambis, 2007) have been demonstrated and it has continued to yield inconsistence results. This assertion calls for examination of the effect of hands-on activity-based on interest of senior secondary schools in organic chemistry.

\section{Research Questions}

The following research questions were answered in this study:

1.What is the difference in the mean interest scores between students taught organic chemistry using hands-on activity-based method and those taught using discussion method?
2.What is the difference in the mean interest scores between male and female students taught organic chemistry using hands-on activity-based method?

\section{Hypotheses}

The following null hypotheses guided the study:

1.There is no significant difference in the mean interest scores between students taught organic chemistry using hands-on activity-based method and those taught using discussion method.

2.The difference in the mean interest scores between male and female students taught organic chemistry using hands-on activity-based method is not significant.

\section{METHODOLOGY}

The purpose of the research was to investigate the effect of hands-on activity-based method on interest of senior secondary students in organic chemistry. The study adopts quasi experimental design. The study area was Makurdi Local Government Area of Benue State, Nigeria. The population of the study comprised all the 2,381 SSII students in the 42 granted aided schools. 184 students were purposively sampled from 4 of the schools that had some basic facilities and equipment in their laboratories. One instrument known as Organic Chemistry Interest Inventory (OCII) was used to collect data for this study. OCII was validated by two experts from science education and one expert from measurement and evaluation from Benue State University, Makurdi. Corrections and suggestions arising from these experts were used to review the instrument before it was used.

OCII is a researcher made 25 -item questionnaire which was intended to help students express their interest toward organic chemistry. Each of the items is a 5-point Likert-rating scale with 5 response options. The options are Strongly Agree (SA), Agree (A), Undecided (U), Disagree (D), and Strongly Disagree (SD). OCll were administered twice as pre- test and post. The reason for Pre-OCII and Post-OCII is to ascertain students' interest before and after treatment. Cronbach Alpha was used to obtain the OCII reliability, which yielded a coefficient value of 0.84 . Mean and Standard Deviation Scores of the collected data were used to answer the research questions while the null hypotheses were tested at 0.05 level of significance using Analysis of Covariance.

\section{RESULTS}

Presentations in this section are based on research questions and hypotheses: 
Table 1: Mean Interest and Standard Deviation Scores of Students taught Organic Chemistry using Hands-on Activity-Based Method and Discussion Method.

\begin{tabular}{lcccccc}
\hline Group & $\mathbf{N}$ & \multicolumn{2}{c}{ PRE-TEST } & \multicolumn{2}{c}{ POST-TEST } & \\
\cline { 3 - 6 } & & $\boldsymbol{x}$ & $\boldsymbol{\delta}$ & $\boldsymbol{x}$ & $\boldsymbol{\delta}$ & Mean Gain \\
\hline Hands-on Activity-based & 91 & 13.64 & 1.78 & 29.43 & 2.14 & 15.79 \\
Discussion & 93 & 13.61 & 1.76 & 16.34 & 1.97 & 2.73 \\
Mean difference & & 0.03 & & 13.09 & & 13.06 \\
\hline
\end{tabular}

Table 2: Mean Interest and Standard Deviation Scores of Male and Female Students taught Organic Chemistry using Hands-on Activity-Based Method.

\begin{tabular}{lcrrrrr}
\hline Sex & \multirow{2}{*}{$\mathbf{N}$} & \multicolumn{2}{c}{ PRE-TEST } & \multicolumn{2}{c}{ POST-TEST } & \\
\cline { 3 - 6 } & & $\boldsymbol{x}$ & $\boldsymbol{\delta}$ & $\boldsymbol{x}$ & $\boldsymbol{\delta}$ & Mean Gain \\
\hline Male & 49 & 11.29 & 1.11 & 23.78 & 1.86 & 12.49 \\
Female & 42 & 11.22 & 1.09 & 22.92 & 1.81 & 11.70 \\
Mean difference & & 0.07 & & 0.86 & & 0.79 \\
\hline
\end{tabular}

\section{Research Question One}

What is the difference in the mean interest scores between students taught organic chemistry using handson activity-based method and those taught using discussion method? The answer to research question one is contained on table 1 . Results on Table 1 shows that the pre-test and post-test mean interest scores difference for the two groups shows that students in the hands-on activity-based group had higher mean interest scores. There is also a positive difference of 13.06 between the post-test mean scores of the two groups in favour of the hands- on activity-based. This suggests that students taught using hands-on activity-based method had higher interest in organic chemistry than their discussion group counterparts.

\section{Research Question Two}

What is the difference in the mean interest scores between male and female students taught organic chemistry using hands-on activity-based method? The answer to research question two is presented on table 2 . Table 2 reveals that the mean difference of both sexes was 0.79 . This difference though small is in favour of the male students. This implies that male students had slightly higher interest rate than their female counterparts in organic chemistry using hands-on activity-based method.

\section{Hypothesis One}

There is no significant difference in the mean interest scores between students taught organic chemistry using hands-on activity-based method and those taught using discussion method. The ANCOVA Tests result on table 3 reveals that there is a significant difference in the interest rating between hands- on activity-based and discussion methods of teaching in favour of hands-on activity-based $F(1,183)=387.370, P(0.0001<0.05)$. The null hypothesis is therefore rejected. This implies that hands-on activitybased method significantly enhanced students' interest in organic chemistry than discussion method.

\section{Hypothesis Two}

The difference in the mean interest scores between male and female students taught organic chemistry using hands-on activity-based method is not significant. ANCOVA Tests result on table 4 reveals that there is no significant difference between the mean interest scores between male and female students taught organic chemistry using hands-on activity-based $F(1,090)$ $=117.523, \quad P(0.101>0.050)$. The null hypothesis is therefore not rejected. This means that hands -on activitybased method enhanced significantly both male and female students' interest in organic chemistry

\section{DISCUSSION}

The study examined the effects of hands-on activitybased on interest of senior secondary chemistry students in organic chemistry. Hands-on activity-based method of teaching was the independent variable. The results of data analysis showed a mean difference in interest score between hands-on activity- based group and discussion method group is 13.06 in favour of hands-on activitybased. The result of hypothesis one indicated that there was a significant difference in the mean interest scores of students taught organic chemistry using hands -on activity-based and discussion methods in favour of hands-on activity-based. This supports earlier report by Ajayi (2016) who asserted that children learn best and 
Table 3: ANCOVA Tests for Mean Interest Scores of Students taught Organic Chemistry using Hands-on Activity-based Method and Discussion Method.

\begin{tabular}{lcccccc}
\hline Source & Type III sum of square & d & Mean Square & F & Sig \\
\hline Corrected model & $3083.102 a$ & 2 & 529.003 & 195.701 & .000 \\
Intercept & 1611.011 & 1 & 1611.011 & 360.191 & .000 \\
Pre-test & 179.005 & 1 & 179.005 & 181.908 & .000 \\
Method & 3090.120 & 1 & 3090.120 & .38 & .000 \\
Error & 799.300 & $\mathbf{1 8 1}$ & 5.010 & &. & \\
Total & $\mathbf{2 1 7 9 0 0 . 7 0 0}$ & $\mathbf{1 8 4}$ & & & & \\
Corrected Total & $\mathbf{2 8 8 1 . 0 0 0}$ & $\mathbf{1 8 3}$ & & & & \\
\hline
\end{tabular}

a. $\mathrm{R}$ squared $=.356$ (Adjusted R Squared $=.331)$.

Table 4: ANCOVA Tests for Mean Interest Scores of Male and Female Students taught Organic Chemistry using Hands-on Activity-Based Method.

\begin{tabular}{|c|c|c|c|c|c|}
\hline Source & Type III sum of square & $d$ & Mean Square & $\mathbf{F}$ & Sig \\
\hline Corrected model & $1920.120 a$ & 2 & 240.909 & 145.100 & .000 \\
\hline Intercept & 1938.001 & $\overline{1}$ & 1938.001 & 220.005 & .000 \\
\hline Pre-test & 192.005 & 1 & 192.005 & 141.119 & .000 \\
\hline Gender & 54.100 & 1 & 54.100 & 117.523 & .101 \\
\hline $\begin{array}{l}\text { Error } \\
\text { Total }\end{array}$ & $\begin{array}{r}358.908 \\
49004.000\end{array}$ & $\begin{array}{r}88 \\
\cdot \quad 91\end{array}$ & 1.929 & $\cdot$ & $\cdot$ \\
\hline Corrected Total & 300.809 & 90 & & & \\
\hline
\end{tabular}

a. $\mathrm{R}$ squared $=.287$ (Adjusted R Squared $=.232$ ).

have more interest by doing not just by sitting and listening. Furthermore the findings of this study are in conformity with Omosewo (2016) who also affirmed that hands-on activity-based teaching featuring active students' participation in the learning process produces superior results than other methods. Hands-on activitybased method has great effects on students' interest in organic chemistry more so that it helps to practicalize those concepts in organic chemistry which are mostly abstract in nature in order to reduce them to concreteness or to reduce their degree of abstraction. In this way, students are motivated and materials are internalized more easily.

Another major finding in this study was that male students had slightly higher interest than their female counterparts using hands-on activity- based but ANCOVA test shows that the difference was no significant. This finding agrees with the findings of Eze (2010) and AlMustapha (2014) who found that there was no significant statistical difference on the interest of male and female students in Biology. Based on this finding, interest in organic chemistry is therefore not dependent on gender. This means that the age long disparity in organic chemistry between male and female students can be laid to rest with the use of hands-on activity-based method. However, the finding contradicts the finding of Adewale (2013) who found gender disparity in students' interest in favour of female students in physic.

\section{CONCLUSION AND RECOMMENDATIONS}

It is evident from the findings of this study that the use of hands-on activity-based could enhance student interest in organic chemistry. If hands-on activity-based proposed by this study is adopted in organic chemistry teaching and learning, it will likely boost the interest of students. Based on the conclusion, the following recommendation is advised: Hands-on activity-based should be encouraged to be used by chemistry teachers in teaching the organic chemistry in order to enhance students' interest in organic chemistry.

\section{REFERENCES}

Abudullai, A.A. (2013). Teachers' involvement in the use of hand-on laboratory methods in teaching. Int. J. Educ. 3(11): 234-237.

Adewale, M.A. (2013). Effects of inquiry and discussion methods on senior secondary chemistry students' achievement and retention in Biology. Unpublished M.Ed dissertation, Lagos State University, Akoka.

Ajayi, O.V. (2016). Effect of hands-on activities on senior secondary chemistry students' achievement and retention in stoichiometry. Unpublished M.Ed dissertation, Benue State University, Makurdi. 
Al-Mustapha, L. (2014). Relationship of practical work on the achievement of students in Biology. J. Educ. and Pract. 6(4): 234-240

Ayuba, A. (2013). Effect of inquiry approach on students' achievement and interest in Chemistry. Unpublished M.Ed dissertation, Adekunle Ajasin University, Akungba Akoko.

Bamidele, M.A. (2009). Effect of demonstration approach on students interest in Physic. Unpublished M.Ed. dissertation, Federal University of Technology, Akure.

Calsambis, S. (2007). Gender related differences in acquisition of formal reasoning schemata: pedagogic implication of teaching science using inquiry based approach. Int. J. Educ. 23(1): 435-440.

Eze, I. (2010). Effect of concept mapping on students' achievement and interest in Biology. Nig. J. Functional Educ. 7(2): 56-62.
Kingdon, M.N. (2009). Hand on laboratory experiments. Retrieved on 23rd January 2015 from http://www.activitybased/lab-edu/edsujkhaco

Olorunyomi, A.A. (2013). Effect of experiential teaching method on students' achievement in Chemistry. Unpublished M.Ed dissertation, Ekiti State University, Ado Ekiti.

Omosewo, M.A. (2016). Effect of hands-on and mind-on teaching/learning approach on students interest in Chemistry. J. Res. in Sci. Teaching. 2(1): 345- 352

Senese, F. (2010). Introduction to Chemistry. Retrieved on 13th February, 2016 from http://www.psych.stanford.edu/chemistry/.pdf

Tile, M.T. (2013). Effect of activity-based on psychomotor skills acquisition and interest of senior secondary 2 in Biology. Unpublished M.Ed dissertation. Benue State University, Makurdi. 